\title{
Effect of Broken Coffee Beans Particle Size, Roasting Temperature, and Roasting Time on Quality of Coffee Beverage
}

\author{
Ezana Getaneh, Solomon Workneh Fanta (D), and Neela Satheesh (iD \\ Faculty of Chemical and Food Engineering, Bahir Dar Institute of Technology, Bahir Dar University, Post Box: 026, \\ Bahir Dar, Ethiopia \\ Correspondence should be addressed to Solomon Workneh Fanta; solworkneh@gmail.com
}

Received 28 June 2020; Revised 8 November 2020; Accepted 6 December 2020; Published 15 December 2020

Academic Editor: Francisca Hernández

Copyright $(92020$ Ezana Getaneh et al. This is an open access article distributed under the Creative Commons Attribution License, which permits unrestricted use, distribution, and reproduction in any medium, provided the original work is properly cited.

Optimum flavor and aroma of the coffee are developed during the roasting process. However, certain problems exist in the coffee roasting process such as partial charring, over roasting, and poor temperature distribution across the coffee bean (due to the low thermal conductivity of bean), if conditions are not optimized. Hence, uniform temperature distribution across the coffee bean in the roasting process is highly desirable. To achieve these requirements, the broken coffee beans were positioned in a single layer packed bed arrangement using the closed system by circulating hot air. In this experiment, three factors were arranged in a completely randomized design with three levels and three replications. The first factor considered was roasting temperature $\left(200^{\circ} \mathrm{C}, 230^{\circ} \mathrm{C}\right.$, and $\left.260^{\circ} \mathrm{C}\right)$, second factor was roasting time $(5 \mathrm{~min}, 10 \mathrm{~min}$, and $15 \mathrm{~min})$, and third was particle size $(4-6 \mathrm{~mm}$, $2.36-3.35 \mathrm{~mm}$, and $1.7-2.36 \mathrm{~mm}$ ). The initial moisture content of raw beans (cv. Limu) was determined. The data were collected on selective physical properties of roasted coffee beans and sensory acceptability of prepared beverage. The results showed that the physical properties and sensory acceptability are significantly high $(P<0.001)$. It depends on the interaction effect of all the studied factors. Among the studies parameters, roasting temperature of $230^{\circ} \mathrm{C}$ with a particle size range of $4-6 \mathrm{~mm}$ showed the steady transition in dry mass loss and change in bulk density with increase in roasting duration. Coffee roasted at $230^{\circ} \mathrm{C}$ for $10 \mathrm{~min}$ with a particle size of $4-6 \mathrm{~mm}$ showed the highest sensory acceptability score (89.21). In conclusion, it can be said that a temperature of $230^{\circ} \mathrm{C}$, a time of $10 \mathrm{~min}$, and a particle size between $2.36-3.35 \mathrm{~mm}$ and $4-6 \mathrm{~mm}$ are recommended conditions for the roasting process of coffee beans.

\section{Introduction}

Coffee is the most consuming nonalcoholic beverage; its consumption is mainly influenced by its palatable flavor and aroma. The desired quality of coffee is attained after passing through different processing steps such as harvesting, washing, drying, roasting, grinding, and cupping [1]. The quality of coffee significantly varies depending on the origin, preparation method, and variations in processing [2]

In the processing of coffee, roasting is the most important unit operation which influences the sensorial, structural, chemical, and physical changes in green coffee beans. The roasting process is a very important step to achieve particular organoleptic attribute to the coffee brew $[3,4]$. In the roasting process, the coffee beans undergoes to range of elevated temperature for varied durations to achieve desired properties
[5]. Many types of roasters have been manufactured for roasting of the coffee bean. However, most of the coffee roasters are simple cylinder type containing inner baffles for blending and dropping of beans and covered in a gas fired oven $[4,6]$. According to Kocadağlı et al. [7] and Redgwell et al. [8], the major disadvantages of these conventional roasters are higher roasting temperature and durations required to achieve the best quality of roasted coffee. These high temperatures and extended roasting durations (15-18 minutes) resulted in scorching of coffee beans and deposition of oil and char on the roaster chambers and dividers. This made difficult the cleaning and handling of the roasters; in addition, roasted beans may result with smoky aroma. Finally, these conventional coffee roasters are considered as unhygienic [7]. Researchers designed and developed various types of coffee roasters to overcome the problems existed with the conventional ones. 
In many common coffee roasters, smaller beans tend to move with low speed to the center of the bed; poor mixing and low heat transfer rates in the bed transverse area facilitated lesser degree of roasting and lighter colored roasted coffee $[3,9]$. Fluidized bed roasters are used commonly in the roasting of coffee beans for production of instant coffee. These roasters are appreciated for consistency in the roasted coffee quality and high control over the processing parameters. However, these roasters also present issues being suitable for only small quantity of the coffee beans [10]. A spouted bed roaster is a type of fluidized bed roaster; it has a focal point. However, the particles to be roasted in a spouted bed roaster should be smaller in size, and they create unsteady or slugging fluidization [11].

Researchers concluded that hot air roasters yield good quality roasted coffee in comparison with drum roasters. However, hot air roasters require higher operating temperatures and higher air to bean ratios. So, there is a need to minimize the roasting temperatures and demand of high air stream. In addition, most of the recent coffee roaster developers are not considered for the grounded coffee bean roasting practice. However, roasting of the coffee bean particles has benefit of considerable surface zone to volume proportion. Size reduction in coffee beans facilitates lower heat transfer resistance and resulted in low temperature gradient in same amount of heat transfer as compared to whole coffee beans.

Finally, the main objective of the present study was to determine the effect of coffee bean particle size, roasting temperatures, and durations of the coffee roasting process in the closed system circulating hot air in a single layer packed bed arrangement on selected physical and sensory properties of the coffee beans and brew.

\section{Materials and Methods}

2.1. Plant Material. Ten kilograms of export standard Limu variety green coffee (C. arabica) beans were provided by Ethiopian Coffee and Tea Authority, Coffee Quality Inspection and Certification Center (ECTACQICC), Addis Ababa, Ethiopia. The green coffee samples used in this experiment were harvested in January, and the experiment was conducted from April to July 2019. Impurities (husk), irregular beans (piece of parchment), and beans with visual defects (black color or attacked by insects) were manually separated and not considered for the roasting process. Then, cleaned coffee beans were packed in polyethylene bags and stored at room temperature until raw quality assessment and roasting experiment were performed.

2.2. Experimental Design. This experiment was designed by the factorial design with three factors arranged in completely randomized design (CRD). The factors considered were roasting temperature, time, and particle size with three levels. Temperature ranges selected in this study were based on the characteristics of coffee beans. As the roasting temperature reached to $190-220^{\circ} \mathrm{C}$, the smoke was released and the typical flavor of roasted coffee was developed [12].
However, to facilitate the good heat transfer in coffee roasting process, the hot air should be greater than $190^{\circ} \mathrm{C}$; so, in this study, $200^{\circ} \mathrm{C}$ was taken as the initial roasting temperature. In case of upper limit of the roasting temperature, $260^{\circ} \mathrm{C}$ was selected by considering the effect of the poor thermal conductivities of the coffee beans and hot air [13]. Hence, the roasting temperature used in this experiment was $200^{\circ} \mathrm{C}, 230^{\circ} \mathrm{C}$, and $260^{\circ} \mathrm{C}$. The roasting durations were selected based on the previous scientific reports published on coffee roasting. According to the Nagaraju et al. [11], a fluidized spouted bed roaster requires 1.5-6 minutes (at roasting temperature range of $310-360^{\circ} \mathrm{C}$ ) and a cylinder roaster requires $8.5-20$ minutes (at roasting temperature range of $400-550^{\circ} \mathrm{C}$ ) of roasting time. In this study, the roasting durations of minimum $5 \mathrm{~min}$ and maximum of $15 \mathrm{~min}$ were set as the roasting durations. So, the roasting durations of three levels $(5,10$, and $15 \mathrm{~min})$ were used in this experiment. The particle sizes were considered by the availability of standard sieves; for this factor, three levels were used as $1.7-2.36 \mathrm{~mm}, 2.36-3.35 \mathrm{~mm}$, and $4-6 \mathrm{~mm}$. All the treatments were carried on triplicate, and the total experimental runs conducted in this study were 81 .

\subsection{Experimental Description and Procedure. The coffee} bean samples brought from ECTACQICC was screened using a standard sieve to remove the fragmented coffee beans $<4 \mathrm{~mm}$ in size and discarded. Then, the sound quality beans were used for determination of their raw value (color, shape, and appearance) using ECTACQICC standard by the help of expert panelists [14].

Before the roasting process was carried, the cleaned beans were dried in a hot air oven (model: M40-VF bernareggio, Italy) at $105^{\circ} \mathrm{C}$ for 3 hours, and they were grounded using the Nima coffee grinder (model: T-001 Nima 8300, India). Further, desired sizes of broken beans were separated by using standard sieves (Retsch, AS200 control, Germany) as specified in the experimental design. The size-sorted broken coffee particles were roasted at designed temperature and time and cooled at room temperature. For each run, $12 \mathrm{~g}$ of roasted coffee beans was collected after the roasting time is completed using a crucible and stored in polythene bag, sealed tightly until further analysis was performed.

2.4. Configuration of the Roaster. In order to achieve good hot air circulation, uniformly sized broken coffee beans were placed in a stainless-steel perforated plate. These plates were placed near to the oven fan operated by forced ventilation and natural air convection facilitated with opening and closings for air (model: M40-VF bernareggio, Italy) as given in Figure 1. During the roasting process, $50 \mathrm{~g}$ of the sample was placed inside the oven, inward and outward flow of air was blocked, and roasting was performed at specified temperature for desired durations.

The following data on green coffee beans, roasted coffee bean particles, and prepared coffee brew were collected according to the standard procedures. 


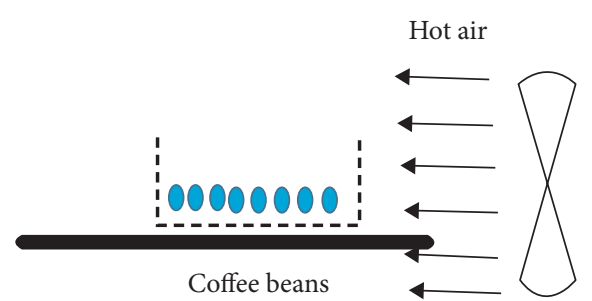

FIGURE 1: Experimental setup of packed bed roaster used in the present study.

2.5. Descriptive Sensory Analysis of the Raw Material. Around $40 \%$ quality of roasted coffee depends on the raw coffee bean quality [14]. So, five expert panelists from Ethiopian Commodity Exchange (ECX) were invited to characterize the raw coffee beans quality. Around $350 \mathrm{~g}$ of green coffee beans was provided to each expert panelist to inspect the quality according to the ECTACQICC standard evaluation format [14], and this process was repeated for five times. Secondary raw values of the green coffee beans were evaluated according to both Ethiopian and Specialty Coffee Association of America (SCAA) standards [15].

According to ECX procedure (ECX, 2011), $350 \mathrm{~g}$ of green beans per sample was allowed for raw bean quality attributes (primary defect, secondary defect, make, shape, color, and odor) evaluation. The primary defects considered those beans in full black, full sour, fungus attacked, insect damaged beans, and presence of foreign matter. According to SCAA, the secondary defects considered are beans in partial black, partial sour, slightly insect damaged floater, immature, withered, and presence of shell. In case of Ethiopian standards, the secondary defects are foxy, underdried, overdried, mixed-dried, stinker, faded, coated, light, and starved beans. In case of the coffee color in both, the standards were evaluated as bluish, grayish, greenish, coated, and faded variations. The odor was evaluated based on the properties such as clean, fairly clean, trace light, moderate, and strong. The make and shape was evaluated as very good, good, fairly good, average, and small. The scoring scales for primary and secondary defects were ranged from 0 to 15 points. In case of makeup, shape and colors were evaluated on the $0-5$ point scale. The odor was evaluated on the scale range of $0-10$. The total primary and secondary qualities of the green coffee were considered for maximum 40 points.

2.6. Determination of Moisture Content. The moisture content of the green coffee grains was determined according to Burmester and Eggers [13]. Initially, the mass of empty moisture dish $\left(M_{1}\right)$ was determined, and then, $50 \mathrm{~g}\left(M_{2}\right)$ of sample was taken in the moisture dish. The samples were placed in a hot air oven at $105^{\circ} \mathrm{C}$ until it reaches to constant weight $\left(M_{3}\right)$. The moisture content in wet base was calculated according to the following equation.

$$
\text { Moisture content }(\%)(\text { wet base })=\frac{M_{2}-M_{3}}{M_{2}-M_{1}} \times 100 \text {. }
$$

\subsection{Physicochemical Characterization of Roasted Bean Particles}

2.7.1. Determination of Bulk Density. Bulk density of the raw and roasted coffee bean samples (broken bean samples) was determined by using the known volume of the pycnometer $\left(V_{p}\right)$. The empty weight of the pycnometer $\left(M_{p}\right)$ and pycnometer weight with the coffee sample $\left(M_{s}\right)$ were determined by the digital balance (Adam Equipment, PW254 laboratory balance, USA). Then, the net mass $\left(M_{n}\right)$ was collected according to equation (2), and bulk density of the sample was determined according to equation (3) [16].

$$
\begin{aligned}
M_{n} & =\left(M_{s}+M_{p}\right)-M_{p}, \\
\text { Bulk density }\left(\frac{g}{L}\right) & =\frac{M_{n}}{V_{p}}
\end{aligned}
$$

2.7.2. Determination of Dry Mass Loss. The total dry mass loss of the coffee bean sample was determined according to the method given by Clarke and Vitzthum [3]. The mass was measured for the dried raw coffee bean samples before $\left(W_{i}\right)$ and after roasting $\left(W_{f}\right)$. The dry mass loss was calculated according to the following equation.

$$
\text { Dry mass loss } \%=\frac{W_{i}-W_{f}}{W_{i}} \times 100 \text {. }
$$

2.7.3. Sensory Analysis of the Coffee Beverage. Twelve grams of roasted coffee bean were grounded by the Nima grinder (model: T-001 Nima 8300, India) and brewed in $250 \mathrm{ml}$ of boiled water based on ECTACQICC standards. Five expert panelists were invited to evaluate the sensory evaluation attributes of cup cleanness, acidity, body, and flavor for seven times based on ECTACQICC standard and recorded their sensory scores. The panelists were instructed to rinse their mouth with drinking water between testing each sample to avoid the residual effect [17]. All the sensory evaluations were conducted at 10:00-10:30 am in the morning and 3:00-3:30 pm in the afternoon to avoid the hunger effect on the sensory evaluation process [18].

2.7.4. Determination of Caffeine Content. The caffeine content was determined according to the Khalid et al. [19] method. The standard calibration curve was prepared by $100 \mathrm{ppm}$ stock caffeine solution. Working standards of 10 , $20,30,40$, and $50 \mathrm{mg} / \mathrm{L}$ were prepared from the stock caffeine solution. Absorbance of each aliquot solution was measured at the absorption maximum of $205 \mathrm{~nm}$ by using a UV-visible spectrophotometer (Perkin Elmer lambda 35, Singapore).

The caffeine content in the roasted coffee was extracted by taking $5 \mathrm{ml}$ of brewed coffee in a separating funnel followed by addition of $1 \mathrm{ml}$ sodium carbonate solution $(20 \mathrm{~g}$ sodium carbonate into distilled water in a $25 \mathrm{ml}$ volumetric flask) and $20 \mathrm{ml}$ of chloroform. The caffeine was extracted by 
inverting the separating funnel for three times, and the nonaqueous chloroform layer was separated. The absorbance of the caffeine extract was measured by UV-visible spectrophotometer at $205 \mathrm{~nm}$ using a quartz cuvette. The amounts of the caffeine content in the samples were determined from the prepared standard graph.

2.8. Data Analysis. Data were analyzed using the Minitab version 19.2 statistical software. The analysis of variance (ANOVA) was determined, and the means were separated by Tukey and considered significant at $P<0.05$.

\section{Results and Discussion}

3.1. Raw Value and Moisture Content of the Green Coffee Samples. The average defect value of green coffee bean sample was observed as 9.6 and 8.8 for primary and secondary defects, respectively. Primary defects value indicates the presence of full black, full sour, fungus attacked, and insect damaged beans; foreign matters were very minimal in green coffee bean samples used in this study [14]. A secondary defect score of 8.8 was observed out of 10 . This indicated that the coffee beans used in this study contained shells and immature or mixed-dried beans due to the nonuniform growth of coffee bean and variation in handling methods after harvesting. The evaluators did not observe any defect in odor for the raw bean and scored 10 out of 10 . In case of appearance, the score was 4.6 out of 5 , which indicated that presence of the irregularity in the shape of coffee beans. These defects may be due to the damage occurred during the washing process and in storage. The color score of the raw beans was 4.6 out of 5 , and this denotes that beans color is faded due to secondary defect made color variation across the beans. The cumulative overall raw coffee bean quality score was 37.6 out of 40 . The mean moisture content was observed as $8.45 \%$, and this moisture content is in agreement with the International Coffee Organization Criteria. The moisture content of dried coffee bean should range between $8 \%$ and $12.5 \%$ [20].

\subsection{Physical Properties of Roasted Coffee Beans}

3.2.1. Dry Mass Loss. Dry mass loss of the roasted coffee showed a significant difference $(P<0.001)$ in all the interaction effects of studied parameters (temperature, particle size, and roasting time) (Table 1 ). The dry mass loss of coffee bean particle size of 4-6 $\mathrm{mm}$ represented by a bar graph as a function of roasting temperature and time is given in Figure 2(a). The dry mass loss of the $4-6 \mathrm{~mm}$ coffee beans particles increased as roasting temperature and roasting time increased. This is may be due to the escaping of the organic matter in the form of smoke in the coffee beans roasting process [8]. Coffee bean particles $(4-6 \mathrm{~mm}$ in size) roasted at $260^{\circ} \mathrm{C}$ showed higher loss of dry mass as roasting time increased (9.53-28.14\%). In contrast, roasting temperature at 200 o C resulted in lowest dry mass loss for all the studied roasting durations for $4-6 \mathrm{~mm}$ sized coffee bean particles (2.73-5.35\%) Table(1). This trend may be occurred due to the insufficient heat transfer from hot air to the bean in the lower roasting temperature. Roasting temperature at $230^{\circ} \mathrm{C}$ showed moderate (9.55-13.85\%) dry mass loss as the roasting time increased for $4-6 \mathrm{~mm}$ coffee beans particles, and this is in agreement with previous reports [4]. Around $30 \%$ of higher dry mass loss was observed in the coffee bean particles roasted at higher temperature $\left(260^{\circ} \mathrm{C}\right)$ and higher roasting times (15 min) than the report of Perrone et al. [21]. This trend may be due to the convoluted shape of the bean particles; they facilitate uniform temperature distribution to facilitate good roasted coffee, but the outer layer of the coffee beans gets roasted high and results in high dry mass loss.

The dry mass loss of the particle size ranged from $2.36 \mathrm{~mm}$ to $3.35 \mathrm{~mm}$ against roasting time and temperatures is shown in Figure 2(b). Similar to the coffee particle size of 4-6 mm, the dry mass loss of the coffee bean particle size of $2.36-3.35 \mathrm{~mm}$ increased as there is rise in temperatures at all the studied roasting durations (Table 1 ). This may be due to the escape of the organic matter as smoke in the roasting process [8]. In case of all the studied roasting times, higher dry mass loss was observed in the coffee bean with the particle size of $2.35-3.35 \mathrm{~mm}$. However, compared to the dry mass loss of the $4-6 \mathrm{~mm}$ coffee bean particle samples, the higher dry mass loss was observed in $2.35-3.35 \mathrm{~mm}$ sized bean particles at all roasting temperatures and durations (Table 1). This trend may be attributed to the interaction of size reduction and extended durations used in the roasting process. The least dry mass loss was observed at $200^{\circ} \mathrm{C}$ roasting temperatures for all studied roasting durations. The dry mass loss $(16.91 \%)$ of the $2.35-3.35 \mathrm{~mm}$ sized coffee beans roasted at $260^{\circ} \mathrm{C}$ for $10 \mathrm{~min}$ are in the range of recommended (15-18\%) dry mass loss for medium to dark roasted coffee beans [4]. In case of $260^{\circ} \mathrm{C}$ roasting temperature at $15 \mathrm{~min}$, dry mass loss is higher $(33.13 \%)$ than the recommended. This high dry mass loss may cause the degradation of essential flavors and organic matter in the roasted coffee beans. Perrone et al. [21] reported lower loss of dry mass compared with the present study. This may be due the usage of high roasting temperature and time in the present study than in Perrone et al.' [21] study. In addition, the larger size of the whole green coffee bean offers high mass transfer resistance than the size reduced beans particles as used in the present study.

The dry mass loss of the raw coffee bean particle size ranged from $1.7 \mathrm{~mm}$ to $2.36 \mathrm{~mm}$ represented by a bar graph as a function of roasting time and temperature is given in Figure $2(\mathrm{c})$. The coffee bean particles $(1.7-2.36 \mathrm{~mm})$ roasted at $260^{\circ} \mathrm{C}$ caused high dry mass loss in comparison with roasting performed at $200^{\circ} \mathrm{C}$ at all the studied roasting durations. In case of all the studied roasting temperatures and durations, the dry mass loss of the roasted coffee bean particles $(1.7-2.36 \mathrm{~mm})$ showed nonlinearity. This trend may be attributed to the reduction of porosity with a lower particle size of the coffee beans. It is clear that, in lower roasting temperature $\left(200^{\circ} \mathrm{C}\right)$, the air movement is decreased than in the higher temperatures $\left(230^{\circ} \mathrm{C}\right.$ and $\left.260^{\circ} \mathrm{C}\right)$ of roasting (Table 1$)$. The coffee bean particle size of $1.7-2.36 \mathrm{~mm}$ showed higher dry mass loss than the whole coffee bean subjected to the same roasting condition as reported by Eggers and Pietsch [4]. This 


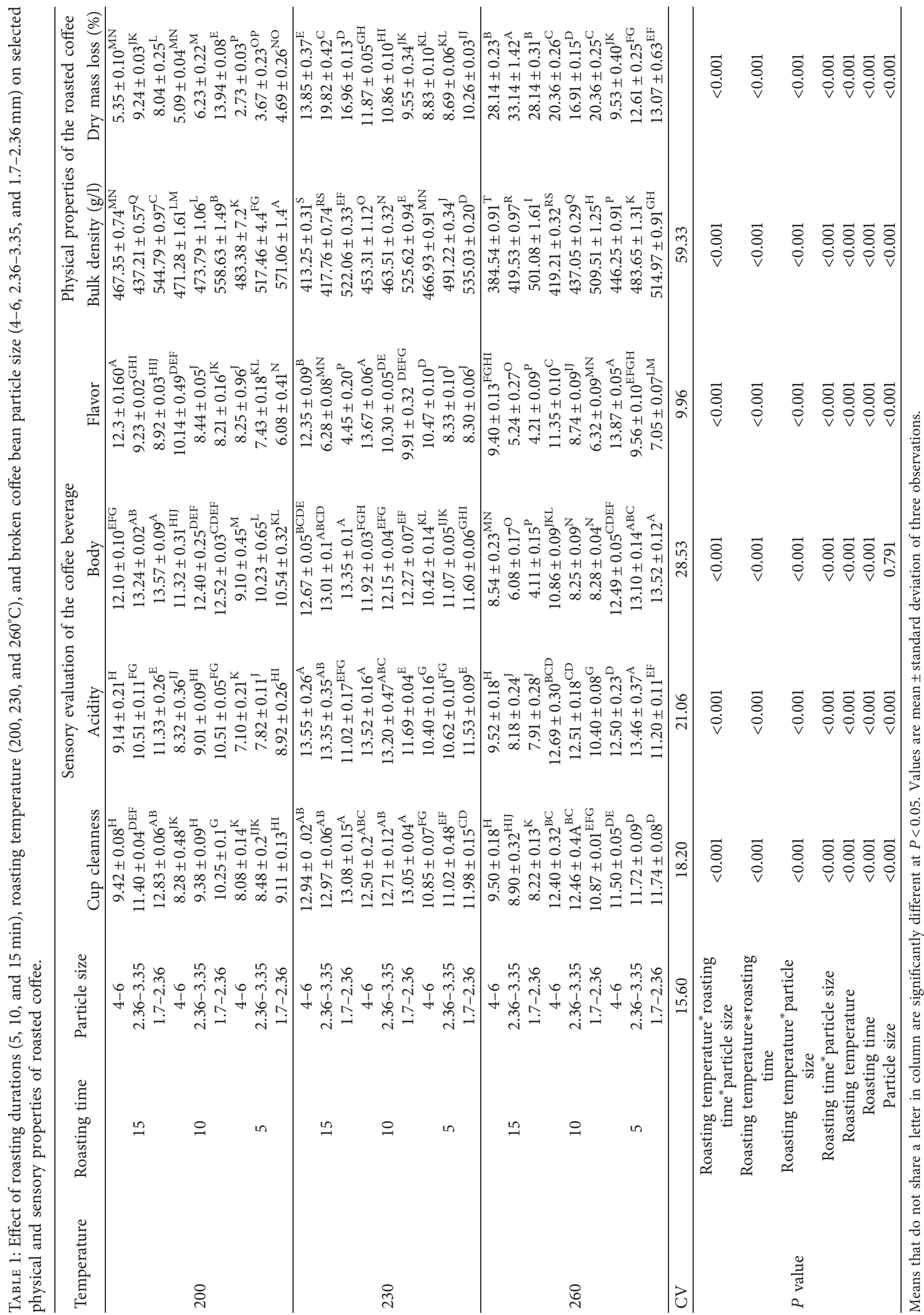




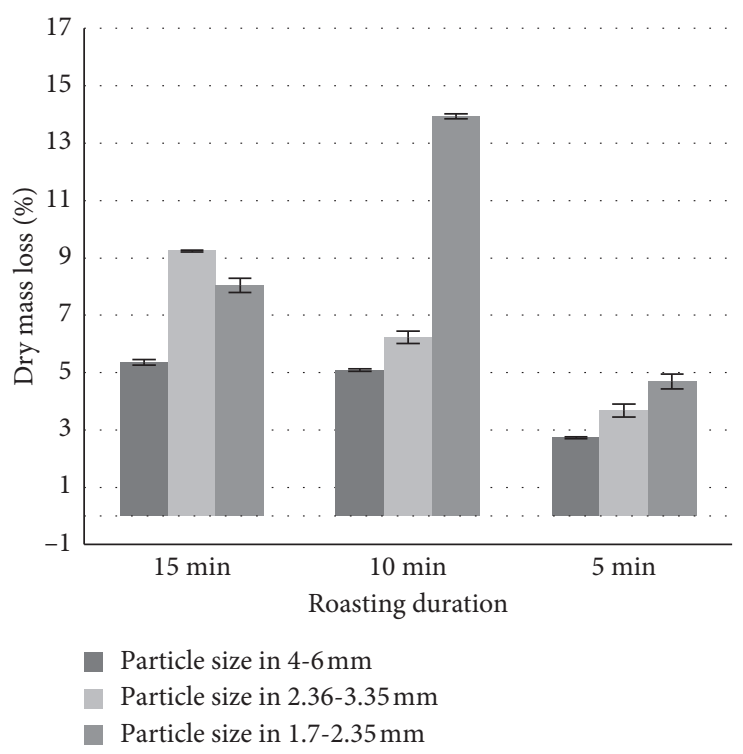

(a)

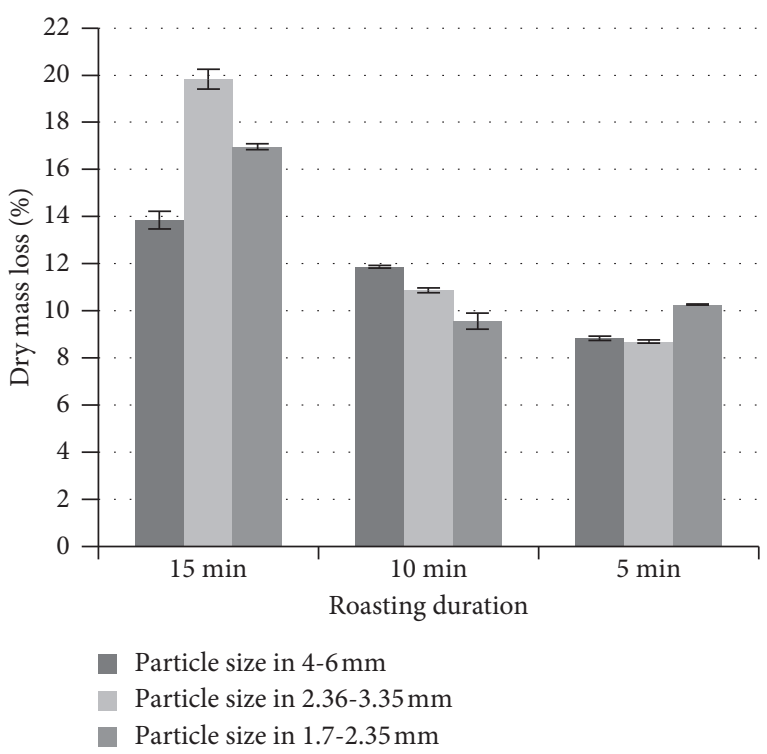

(b)

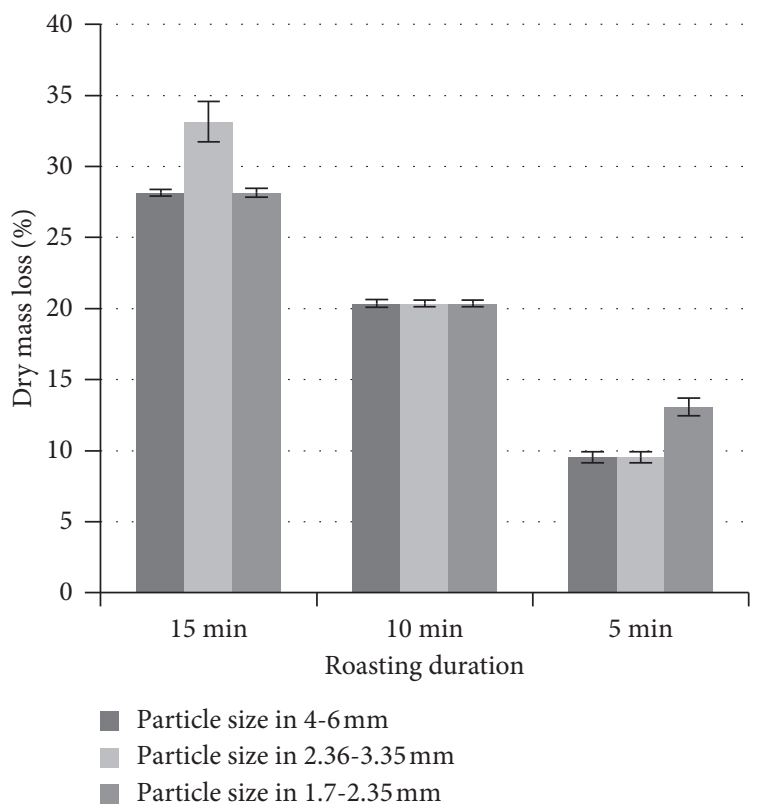

(c)

FiguRe 2: Effect of bean particle size, roasting temperature, and time on the dry mass loss (\%) of roasted coffee beans. (a) Roasting temperature at $200^{\circ} \mathrm{C}$. (b) Roasting temperature at $230^{\circ} \mathrm{C}$. (c) Roasting temperature at $260^{\circ} \mathrm{C}$.

trend may be due to the reduction in particle sizes; the good heat and mass transfer was facilitated in the roasting process. This resulted in higher organic matter loss than the ungrounded coffee beans.

3.2.2. Change in Bulk Density. Bulk density of the roasted coffee beans was significantly high $(P<0.001)$. It depends on the all main and interaction effects of the particle size, roasting size, and roasting temperatures (Table 1).

The mean bulk density of the green coffee bean particle size of 4-6 mm was observed as $550 \mathrm{~g} / \mathrm{L}$. Figure 3(a) shows the changes in the bulk density of the coffee bean as the roasting temperature and durations increased. At $200^{\circ} \mathrm{C}$ of roasting temperature, roasted coffee beans bulk density was observed in the range of $467-483 \mathrm{~g} / \mathrm{L}$ for all the roasting durations in the case of 4-6 mm sized coffee bean particles. The loss in the bulk density was ranged from $14.5 \%$ to $10.9 \%$ for $4-6 \mathrm{~mm}$ sized beans roasted at $200^{\circ} \mathrm{C}$ as compared with initial bulk density (Table 1). Roasted coffee beans at $230^{\circ} \mathrm{C}$ showed bulk density of $413.25 \mathrm{~g} / \mathrm{L}$ to $525 \mathrm{~g} / \mathrm{L}$ as the roasting time varied from $5 \mathrm{~min}$ to $15 \mathrm{~min}$ for $4-6 \mathrm{~mm}$ sized coffee bean particles. In case of $260^{\circ} \mathrm{C}$ roasting temperature, the loss in bulk density of $30.9-20 \%$ (384-446 g/L) was observed for 4-6 mm coffee bean particles (Table 1). 


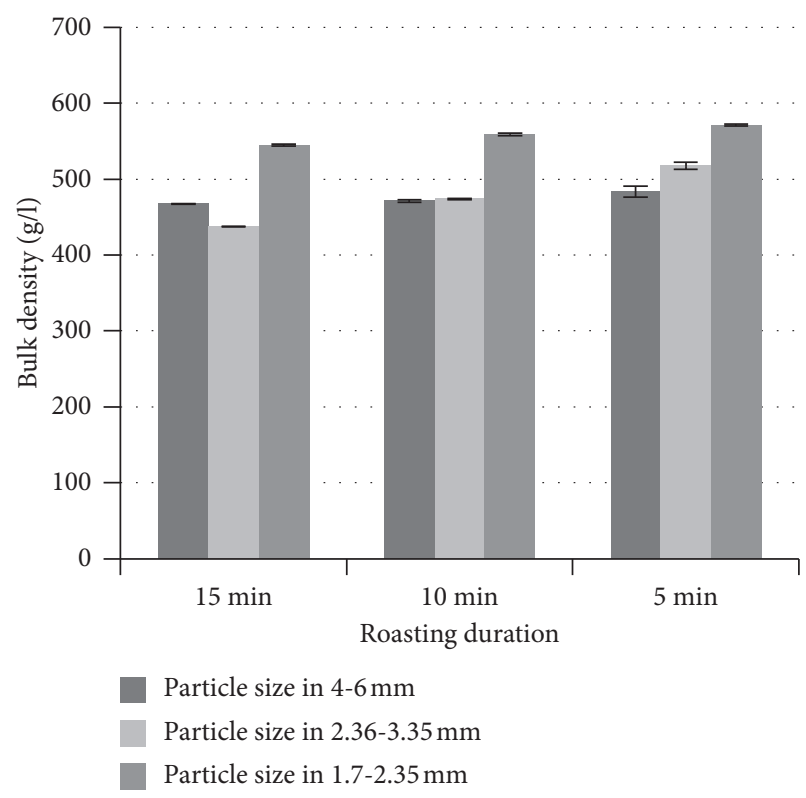

(a)

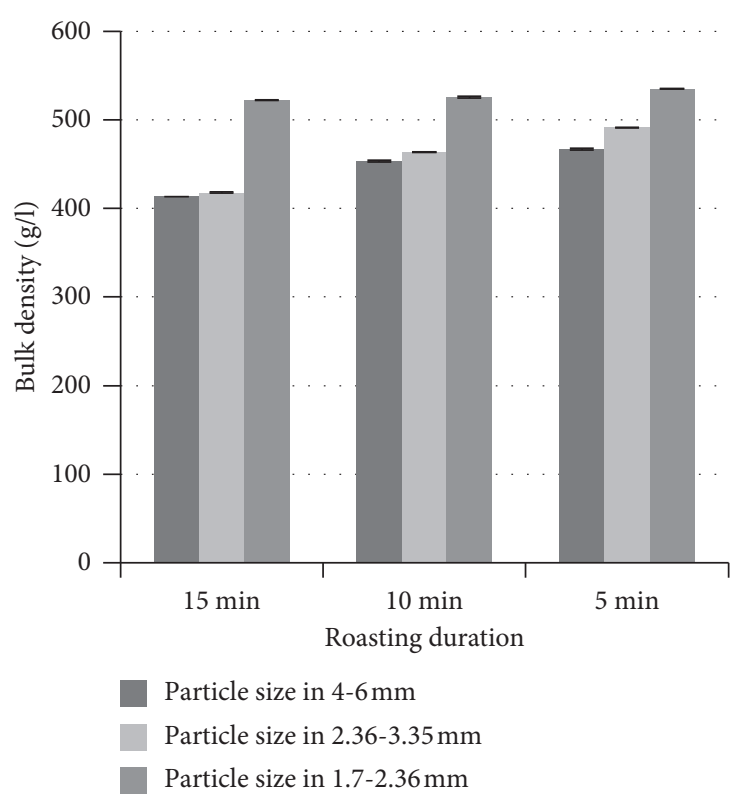

(b)

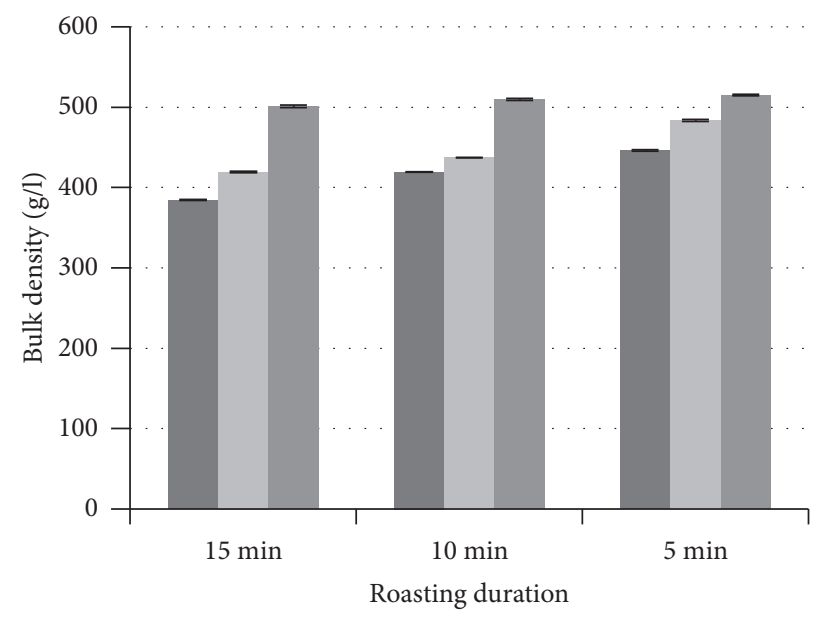

Particle size in 4-6 mm

Particle size in $2.36-3.35 \mathrm{~mm}$

Particle size in $1.7-2.36 \mathrm{~mm}$

(c)

Figure 3: Effect of coffee bean particle size, roasting temperature, and time on the bulk density of the coffee bean. (a) Roasting temperature at $200^{\circ} \mathrm{C}$. (b) Roasting temperature at $230^{\circ} \mathrm{C}$. (c) Roasting temperature at $260^{\circ} \mathrm{C}$.

Coffee bean particles $(4-6 \mathrm{~mm})$ roasted for shortest durations $(5 \mathrm{~min})$ at highest roasting temperature $\left(260^{\circ} \mathrm{C}\right)$ observed linear decrease in bulk density due to the proportional changes in the bean volume and mass (Table 1). These changes in volume and mass allowed the escape of the organic matter in form of smoke at high roasting temperatures [22]. In contrast, at $10 \mathrm{~min}$ and $15 \mathrm{~min}$ roasting durations for $4-6 \mathrm{~mm}$ sized coffee bean particles, the bulk density decreased after $230^{\circ} \mathrm{C}$ of roasting temperatures. This implies that, at $10 \mathrm{~min}$ of roasting time, as roasting temperature increases, the mass leaves higher and expansion of the bean volume reduces [23]. In case of 4-6 $\mathrm{mm}$ sized coffee bean particle, at roasting temperature of $230^{\circ} \mathrm{C}, 15 \mathrm{~min}$ of the roasting durations, the volume almost reached to its final capability, but the amount of mass loss reduced progressively [24].

The raw coffee bean in the range of $2.36-3.35 \mathrm{~mm}$ particle size showed bulk density of $563 \mathrm{~g} / \mathrm{L}$. The bulk density of coffee bean particles in $2.36-3.35 \mathrm{~mm}$ size against roasting time and temperatures is shown in Figure 3(b). The coffee bean particle size of $2.36-3.35 \mathrm{~mm}$ roasted at $200^{\circ} \mathrm{C}$ observed bulk density in the range of $437.21-517.46 \mathrm{~g} / \mathrm{L}$ for all the roasting durations and $8.08-22.34 \%$ loss in bulk density. In case of $230^{\circ} \mathrm{C}$, the coffee bean particle size of $2.36-3.35 \mathrm{~mm}$ showed the bulk density in the range of $417-463.51 \mathrm{~g} / \mathrm{L}$ and reported the loss of $17.67-25.93 \%$ in all the studied roasting 
durations. However, in the case of $260^{\circ} \mathrm{C}$ roasting temperatures, the bulk density ranged from $419.05 \mathrm{~g} / \mathrm{L}$ to $483.64 \mathrm{~g} /$ $\mathrm{L}$, and the bulk density loss of $14.20-25.48 \%$ was observed in all roasting durations. Among all the studied roasting temperatures, $260^{\circ} \mathrm{C}$ showed higher loss in the bulk density; this may be due to the high heat transfer to the bean particle, and this facilitated more volatile components escape from the coffee bean (Table 1). In comparison with the coffee bean in the particle size of $4-6 \mathrm{~mm}$, coffee bean with the particle size of $2.36-3.35 \mathrm{~mm}$ showed high loss in bulk density. The smaller-sized bean particles facilitated higher exposure of surface area per unit volume for the studied roasting temperatures, and this is responsible for higher loss in bulk density [21].

The bulk density of the smallest $(1.7-2.36 \mathrm{~mm})$ size green coffee bean particles was determined as $604.29 \mathrm{~g} / \mathrm{L}$. Figure 3(c) shows the changes in the bulk density of the coffee bean (1.7-2.36 $\mathrm{mm}$ ) against the roasting temperature and time. The smallest coffee particles roasted at $200^{\circ} \mathrm{C}$ showed the bulk density in the range of $544.79-571.06 \mathrm{~g} / \mathrm{L}$. Similarly, the loss of bulk density observed was $9.84 \%-5.49 \%$ as the roasting durations varied from $15 \mathrm{~min}$ to $5 \mathrm{~min}$. In case of $230^{\circ} \mathrm{C}$ roasting temperature, bulk density of the roasted coffee bean particles $(1.7-2.36 \mathrm{~mm})$ ranged from $522.06 \mathrm{~g} / \mathrm{L}$ to $535.03 \mathrm{~g} / \mathrm{L}$, and loss of $13.60-11.46 \%$ observed as roasting time varied from $15 \mathrm{~min}$ to $5 \mathrm{~min}$, respectively. In case of $260^{\circ} \mathrm{C}$ roasting temperature, the bulk density of the roasted coffee bean particles $(1.7-2.36 \mathrm{~mm})$ was observed as 501.08-514.97 g/L (17.07-14.78\%). At higher roasting temperatures, the viscosity of the air increases, and the smaller particle size of the broken coffee beans results in lower package porosity, and this limits the flow of hot air circulation [22]. Similarly, the loss in bulk density of the coffee bean particle in $1.7-2.36 \mathrm{~mm}$ size also followed the similar trend with the other two studied particle sizes (Table 1). As the roasting temperature and durations are increased, the loss of the bulk density also raises. The larger initial particle size brings a higher reduction in bulk density as a result of volume expansion.

3.2.3. Sensory Quality (Cup Value) Analysis of Coffee Beverage from Roasted Coffee Beans. Once the coffee was brewed, its sensory quality for cup cleanness, acidity, body, and flavor was evaluated with expert panelists, and each of the sensory attribute results is discussed in the following section.

3.2.4. Cup Cleanness. Cup cleanness is a collective sensory property of different characteristics such as settling property, development and sustainability times of the foam, and overall visual appearance of a brewed coffee. Cup cleanness accounts for $15 \%$ of the total quality of the coffee beverage [14]. The cup cleanness is high significantly $(P<0.001)$ depending on the all main and interaction effects of the studied parameters.

The cup cleanness value of the beverage prepared from the different sized beans roasted at $200^{\circ} \mathrm{C}$ is shown in Figure $4(\mathrm{a})$. In case of all the studied particle sizes $(4-6 \mathrm{~mm}$,
$2.36-3.35 \mathrm{~mm}$, and $1.7-2.36 \mathrm{~mm})$, the cup cleanness values increased from 8.08 to $9.42,8.48$ to 11.4 , and 9.11 to 12.83 , as roasting time varied from $5 \mathrm{~min}$ to $15 \mathrm{~min}$ at $200^{\circ} \mathrm{C}$ roasting temperature. In all the studied particle sizes, the coffee beverage prepared from $1.7 \mathrm{~mm}$ to $2.36 \mathrm{~mm}$ bean particle size was appreciated for a higher cup cleanness value. This may be due to the ease of heat transfer in the smaller particle than larger particles and release of more foaming agents such as galactomannan and arabinogalactan in smaller particles than the large-sized coffee particles [25].

The results of cup cleanness for the coffee beverage prepared from the roasted bean particles at $230^{\circ} \mathrm{C}$ is shown in Figure 4(b). Among the studied particle size of $4-6 \mathrm{~mm}$, $2.36-3.35 \mathrm{~mm}$, and $1.7-2.36 \mathrm{~mm}$, the cup cleanness value increased from 10.85 to $12.94,12.97$ to 11.02 , and 13.8 to 11.98 , respectively, as there is rise in roasting durations from $5 \mathrm{~min}$ to $15 \mathrm{~min}$. High cup cleanness value (13.08) was obtained for the coffee beverage prepared from roasting temperature of $230^{\circ} \mathrm{C}$ for $15 \mathrm{~min}$. Among all the studied particle sizes, coffee beverage prepared from the smaller bean sizes was observed for a higher cup cleanness value. This may be due to the interaction between the hot air and the coffee bean that was boosted at the roasting process. In case of all the studied particle sizes, as the roasting durations increased from $10 \mathrm{~min}$ to $15 \mathrm{~min}$, the acceptability of the cup cleanness approaches was almost same due to the saturation of foaming components (different proteins) in the coffee bean [26].

The cup cleanness results of the coffee beverage prepared from a roasting temperature of $260^{\circ} \mathrm{C}$ are shown in Figure $4(\mathrm{c})$. In case of the studied particle size ranges (4-6 mm, 2.36-3.35 mm, and 1.7-2.36 mm), the cup cleanness values ranged 12.40-9.50, 12.46-8.90, and 11.74-8.22, as roasting time varied from $5 \mathrm{~min}$ to $15 \mathrm{~min}$. Cup cleanness values of the coffee beverage was highly appreciated as the roasting time increased from $5 \mathrm{~min}$ to $10 \mathrm{~min}$; however, as the roasting time reaches to $15 \mathrm{~min}$, the cup cleanness values were decreased. This trend may be due to higher temperature in roasting forms components responsible for foam proteins. As the roasting time increases, the high temperature denatures the foam forming components [27]. In case of coffee beverage prepared from the roasted coffee bean particle size of $1.7-2.36 \mathrm{~mm}$, the cup cleanness acceptability decreased as the roasting time increased. As the particle size reduced, the cup cleanness values decreased; this may be due to the degradation of foam-forming components at higher roasting temperatures $\left(260^{\circ} \mathrm{C}\right)$, and the smaller particles are less denser and do not settle easily in brewed coffee.

3.2.5. Acidity. Acidity value denotes the concentration of coffee extracts in the coffee brew. It accounts for 15\% of the total coffee beverage quality [14]. Acidity of the coffee beverage is high significantly $(P<0.001)$ depending on all the main and interaction effects of the studied factors.

As shown in Figure 5(a), for each studied particle size, the sensory acceptability of acidity increases as the roasting duration increases at $200^{\circ} \mathrm{C}$ of roasting temperature. At the 


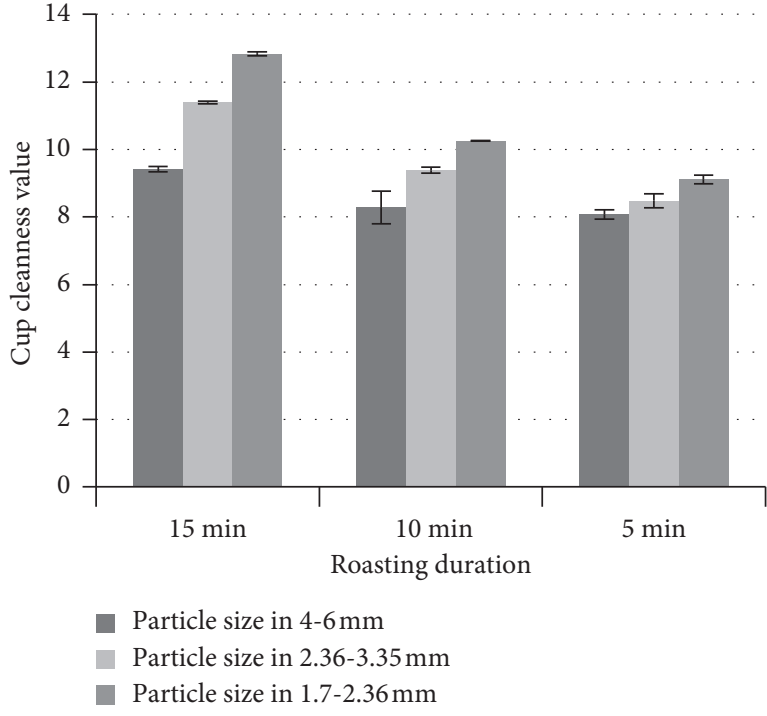

(a)

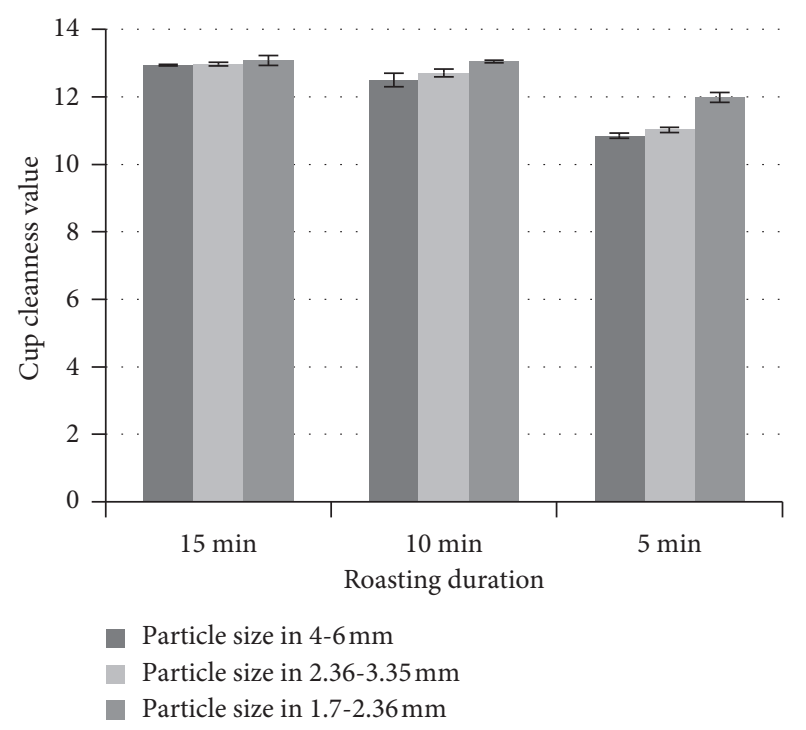

(b)

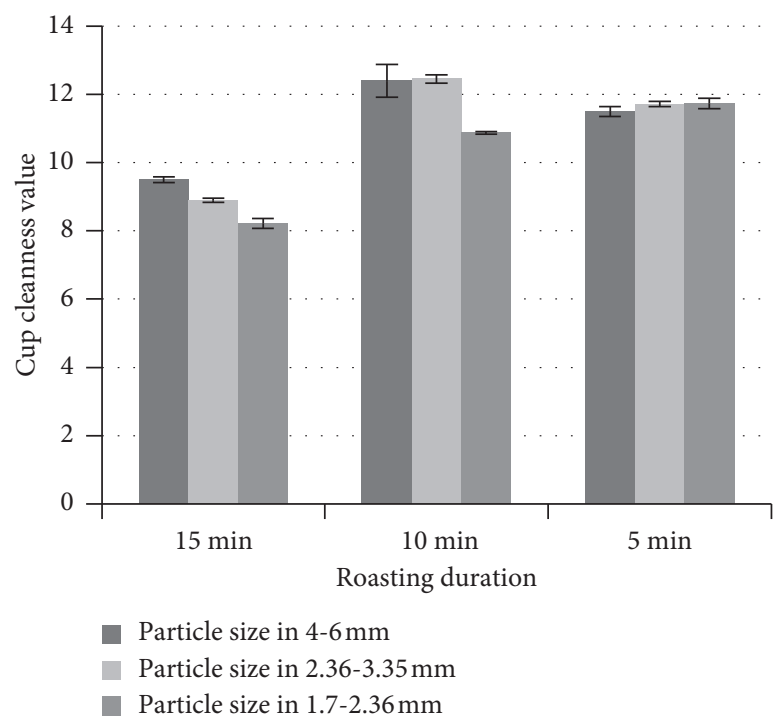

(c)

FiguRE 4: Effect of coffee bean particle size, roasting temperature, and roasting time on the cup cleanness value of the coffee beverage. (a) Roasting temperature at $200^{\circ} \mathrm{C}$. (b) Roasting temperature at $230^{\circ} \mathrm{C}$. (c) Roasting temperature at $260^{\circ} \mathrm{C}$.

roasting temperature of $200^{\circ} \mathrm{C}$, particle sizes of $4-6 \mathrm{~mm}$, $2.36-3.35 \mathrm{~mm}$, and $1.7-2.36 \mathrm{~mm}$ reported the acidity in the range of 5.10-9.14, 7.82-10.52, and 8.92-11.33, respectively, as the roasting durations increased from $5 \mathrm{~min}$ to $15 \mathrm{~min}$. This trend may be attributed to the presence of monosaccharide and polysaccharides in the coffee bean easily available for extraction as the roasting time increased [8]. The coffee beverage prepared from the roasted coffee bean particle size of $4-6 \mathrm{~mm}$ at $200^{\circ} \mathrm{C}$ showed relatively lower cup acidity values. In contrast, coffee beverage from the roasted smallest particles $(1.7-2.36 \mathrm{~mm})$ was appreciated for higher scores of cup acidity. This trend may be due to the smaller particle sizes provide higher surface to volume ratio and facilitate the better extraction of saccharide components into the brew $[8,28]$.
The coffee beverage prepared in the range of $4-6 \mathrm{~mm}$, $2.36-3.35 \mathrm{~mm}$, and $1.7-2.36 \mathrm{~mm}$ particle size, roasted at $230^{\circ} \mathrm{C}$, showed the acidity value in the range of $10.40-13.55$, 10.62-13.35, and 11.02-11.69, respectively (Table 1). As shown in Figure 5(b), coffee beverage prepared from all the studied particle sizes enhanced the acidity value as roasting durations increased from $5 \mathrm{~min}$ to $10 \mathrm{~min}$. However, the acidity value of the coffee beverage starts to decrease for the smallest particle size and maintained constant for the larger particle size at $230^{\circ} \mathrm{C}$ roasting temperature. The monosaccharide and polysaccharides inside the beans degrade easily, for instance, xylose (polysaccharide) completely degrades at $220^{\circ} \mathrm{C}$ [8]. At $230^{\circ} \mathrm{C}$ of roasting temperature, as roasting duration increased, the cup acidity values were decreased in all the studied particle sizes. In comparison with coffee 


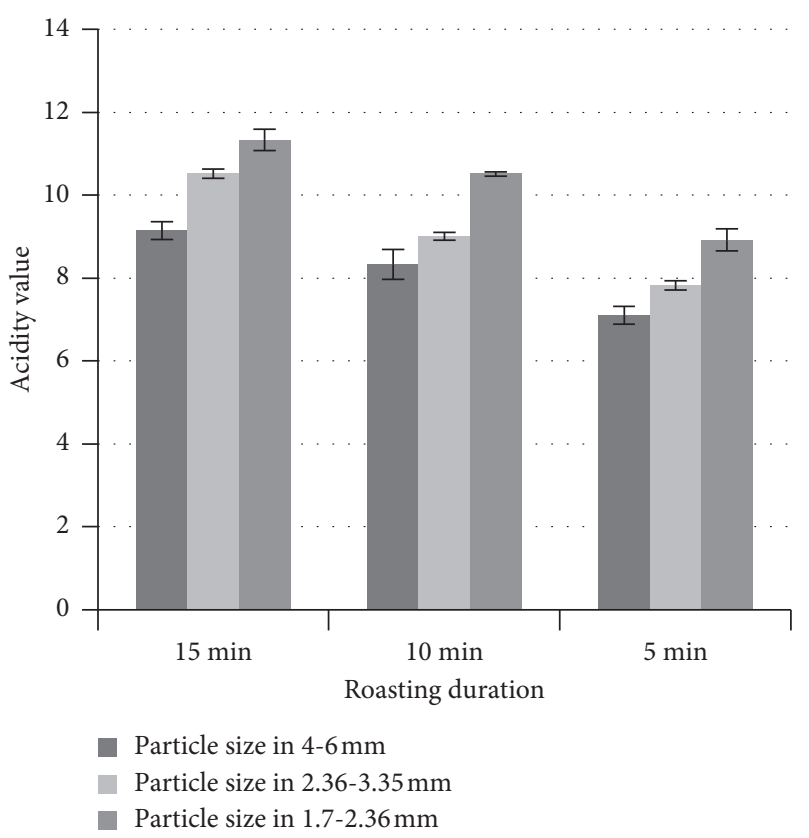

(a)

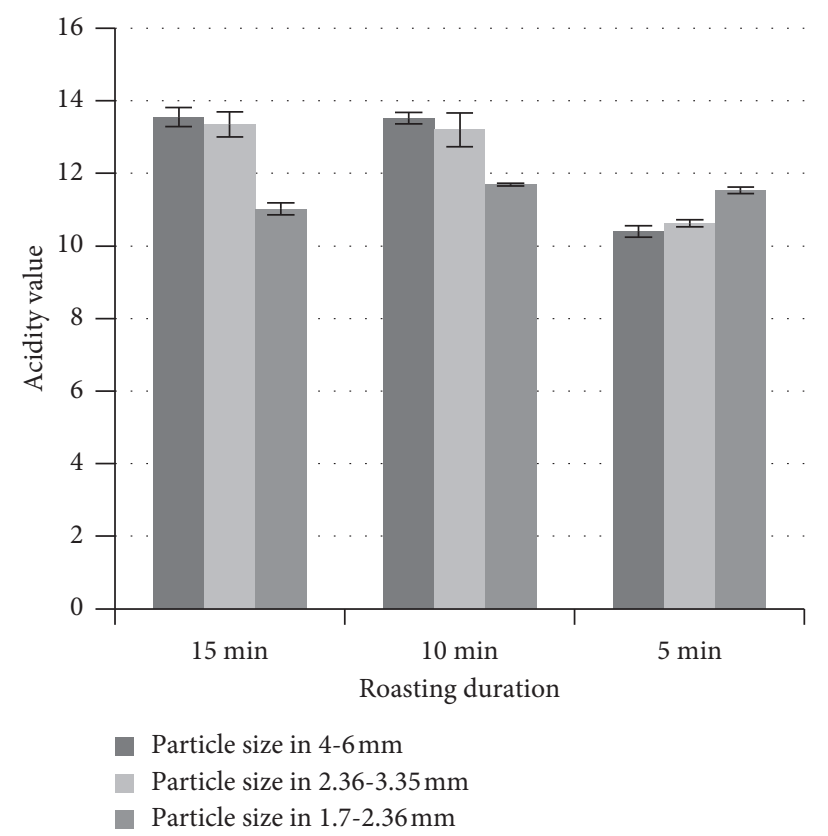

(b)

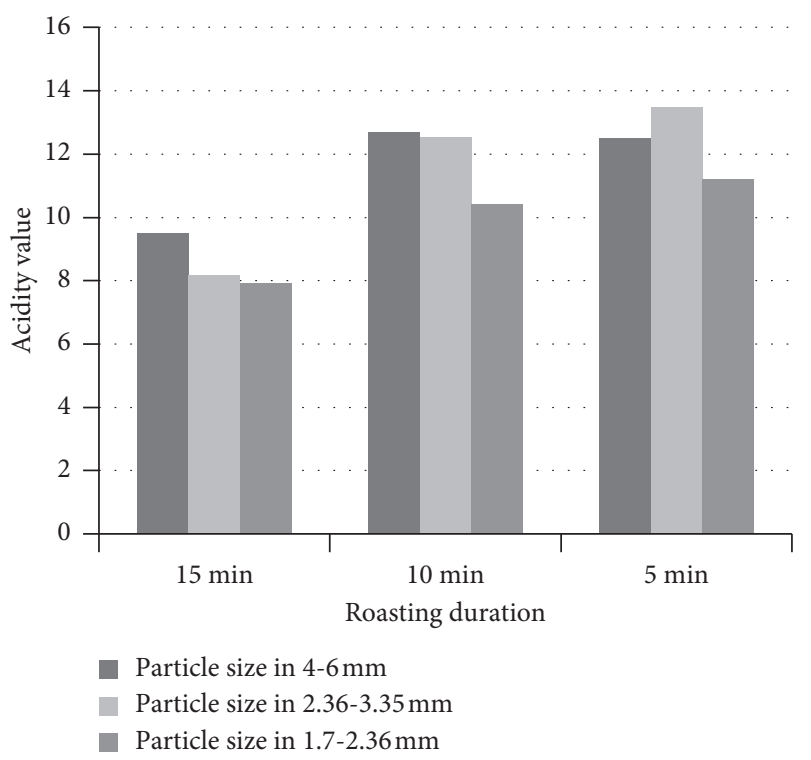

(c)

FIGURE 5: Effect of coffee bean particle size, roasting temperature, and roasting time on the acidity value of the coffee beverage. (a) Roasting temperature at $200^{\circ} \mathrm{C}$. (b) Roasting temperature at $230^{\circ} \mathrm{C}$. (c) Roasting temperature at $260^{\circ} \mathrm{C}$.

beverage prepared from the beans roasted at $200^{\circ} \mathrm{C}$, coffee beverage prepared by the beans roasted at $230^{\circ} \mathrm{C}$ rated lower cup acidity scores for the particles size of $1.7-1.36 \mathrm{~mm}$. Coffee beverage prepared from the particle size of $2.36-3.35 \mathrm{~mm}$ at roasting temperature of $230^{\circ} \mathrm{C}$ roasted for $10 \mathrm{~min}$ appreciated for highest acidity scores.

The coffee beverage prepared from the particle size of $4-6,2.36-3.35$, and $1.7-2.36 \mathrm{~mm}$ roasted at $260^{\circ} \mathrm{C}$ showed the acidity scores in the range of $9.52-12.69,8.18-13.46$, and 7.91-11.20, respectively (Table 1 ). Coffee beverage prepared from smaller-sized coffee particles roasted at $260^{\circ} \mathrm{C}$ gave lower acidity scores. However, coffee beverage prepared from the larger particle size $(4-6 \mathrm{~mm})$ roasted at $260^{\circ} \mathrm{C}$ observed slight increase until $10 \mathrm{~min}$ of roasting times than other particle sizes (Figure 5(c)). This may be due to the effect of high roasting temperature degrades the essential 
polysaccharides $[8,29]$. Coffee beverage prepared from coffee bean roasted for $5 \mathrm{~min}$ at $260^{\circ} \mathrm{C}$ with the particle size of $2.36-3.35 \mathrm{~mm}$ provided a higher cup acidity value in comparison with other studied two particle sizes. However, the coffee beverage from the particle size of 4-6 $\mathrm{mm}$, roasted for $10 \mathrm{~min}$ and $15 \mathrm{~min}$ at $260^{\circ} \mathrm{C}$, resulted in the highest acidity scores in comparison with other two particle sizes. This implies that, size reduction resulted in high acidity scores at the lower roasting time, but not for too smaller particles.

3.2.6. Body Value. The body value of the brewed coffee beverage represents the combined effect of viscosity and mouth feel. It accounts for $15 \%$ of the total quality of the roasted coffee beverage [14]. Coffee body value is high significantly $(P<0.001)$ depending on all the studied interactions and main effect of the times and temperatures. However, particle size is nonsignificantly $(P>0.05)$ effected on the coffee beverage body value.

Body value of the brewed coffee beverage prepared from coffee bean roasted at $200^{\circ} \mathrm{C}$ is depicted in Figure 6(a). As shown in the image, coffee beverage prepared from the particle size of $1.7-2.36 \mathrm{~mm}$, roasted for $15 \mathrm{~min}$, received the highest body value score (13. 57). This trend is may be attributed to the higher extraction of lipids and trigonelline as the size of bean particle was reduced [30]. The coffee beverage prepared from the particle size of $2.36-3.35 \mathrm{~mm}$ received lower cup values (13. 24), and this is followed by $1.7-2.36 \mathrm{~mm}$ particle at $10 \mathrm{~min}$ of roasting time (9.10). As the coffee bean particle size was reduced, the bean did not facilitate the migration of lipids, and the lipids appear on the surface of the beans due to the initial higher concentrations [31]. Similarly, coffee brewed from $4 \mathrm{~mm}$ to $6 \mathrm{~mm}$ particle size reduced in the body value (9.10), but not much difference in the body value was observed in the coffee beverage prepared from the particle size of $2.36-3.35 \mathrm{~mm}(10.23)$ and $1.7-2.36 \mathrm{~mm}$ (10.54), roasted for $5 \mathrm{~min}$ at $200^{\circ} \mathrm{C}$. This trend may be attributed to the poor heat transfer inside the bean caused by its larger size and lower thermal conductivity [32].

The body value of brewed coffee from the bean roasted at $230^{\circ} \mathrm{C}$ is shown in Figure $6(\mathrm{~b})$ against roasting time and temperature. In case of all the studied coffee particle sizes (4-6 $\mathrm{mm}, 2.36-3.35 \mathrm{~mm}$, and $1.7-2.36 \mathrm{~mm}$ ), the body value of the coffee beverage increased as the roasting time increased (Table 1). However, the highest body value was assigned to the brew prepared from $1.7 \mathrm{~mm}$ to $2.35 \mathrm{~mm}$ particle size coffee bean roasted at $15 \mathrm{~min}$. This trend may be due to the overlapping of internal processes such as evaporation and gas formation [33]. As the particle size and roasting time increases, the body value also increased. This trend might be associated with lipid and trigonelline viscosity reduction due to the high temperature in the roasting process, and as the particle size increased, a high mass transfer resistance was observed [31].

The body value of the coffee beverage prepared form the roasted bean at $260^{\circ} \mathrm{C}$ is shown in Figure 6(c). In case of all the treatments, coffee beverage prepared from smaller particle size $(1.7-2.36 \mathrm{~mm})$ received the highest body value score (13.52) for $5 \mathrm{~min}$ of roasting duration. This may be due to the high roasting temperature $\left(260^{\circ} \mathrm{C}\right)$ leads to the degradation of lipids and trigonelline components that occur [34]. This loss was magnified in the brew prepared from particle size range of $1.7-2.36 \mathrm{~mm}$, roasted for $15 \mathrm{~min}$, observed for the least body value (4.11). This may be because of lower resistance for mass and heat flow due to their smaller size.

3.2.7. Flavor. Flavor acceptability of the coffee brew represents the originality in taste of the coffee. It accounts for $15 \%$ in the total quality of the roasted coffee [14]. Flavor of the coffee is high significantly $(P<0.001)$ depending on all main and interaction effects of the studied parameters (Table 1).

The flavor values of the coffee beverage prepared from the beans roasted at $200^{\circ} \mathrm{C}$ against particle size and roasting time are shown in Figure 7(a). As shown in the image, the flavor acceptability of the beverage increased as the roasting time and particle size increased. The flavor value was in the range of 12.3-6.08 among the all studied particle sizes and roasting durations. The highest flavor (12.3) value was obtained to the brew prepared from roasted coffee particle size of $4-6 \mathrm{~mm}$, roasted for $15 \mathrm{~min}$ at $200^{\circ} \mathrm{C}$. In contrast, the lowest flavor (6.08) value was obtained to the brew prepared from smaller particle size $(1.7-2.36 \mathrm{~mm})$ coffee bean roasted for $5 \mathrm{~min}$ at $200^{\circ} \mathrm{C}$. This may be due to the development of bitter taste and escaping of flavor forming organic chemicals due to the lower mass transfer resistance of smaller sized bean particles [35].

Flavor value of the brewed coffee bean roasted at $230^{\circ} \mathrm{C}$ against roasting durations and studied particle size is shown in Figure 7(b). The highest flavor value of 13.67 received for the brew prepared from $2.36 \mathrm{~mm}$ to $3.35 \mathrm{~mm}$ particle size beans and roasted for $15 \mathrm{~min}$. In contrast, the lowest flavor value was observed for the brew prepared from $4 \mathrm{~mm}$ to $6 \mathrm{~mm}$ particle, roasted for $5 \mathrm{~min}$. This may be due to the bitter taste of caffeine and reduction of chlorogenic acid due to higher duration exposure in the roasting process [36].

Flavor values of the coffee brew prepared from beans roasted at $260^{\circ} \mathrm{C}$ are shown in Figure $7(\mathrm{c})$ against the roasting time and particle size. The highest flavor value was observed for the coffee brew prepared from $4 \mathrm{~mm}$ to $6 \mathrm{~mm}$ particle size, roasted for $5 \mathrm{~min}$. In contrast, the lowest flavor value was observed for brew prepared from $1.7 \mathrm{~mm}$ to $2.30 \mathrm{~mm}$ coffee particle, roasted for $15 \mathrm{~min}$. This implies that the highest roasting time and lowest particles sizes are negatively correlated to the flavor value of the coffee brew. As the roasting time increased, flavor components escape the bean in form of gas or undergo different chemical degradations and result in minimum flavor value $[37,38]$.

3.2.8. Caffeine Content. Depending on the sensory acceptability scores of the brewed coffee, four processing conditions were scored as grade 1 (i.e., scored $\geq 85$ ), and these were selected for caffeine content determination. The caffeine content of the roasted coffee is high significantly $(P<0.001)$ 


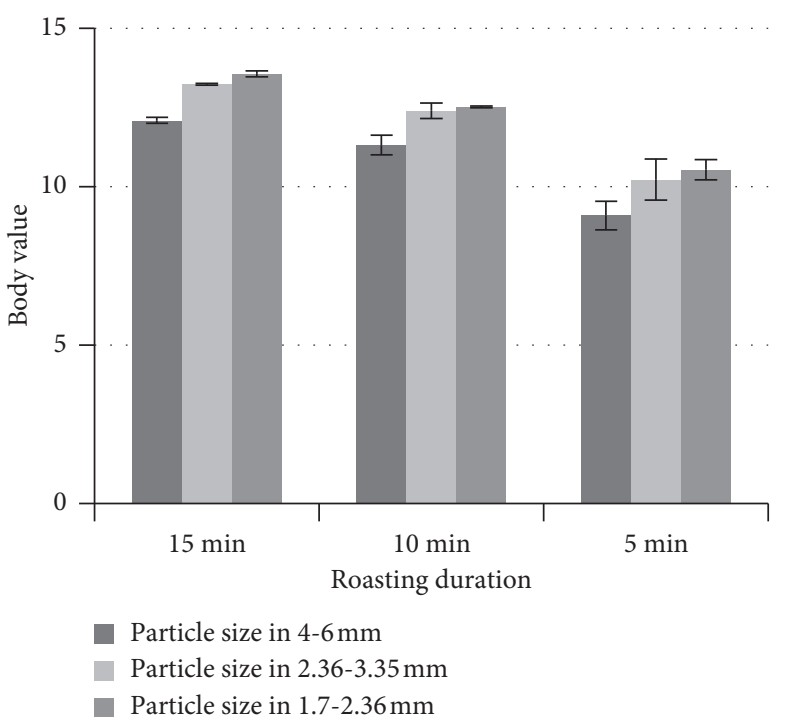

(a)

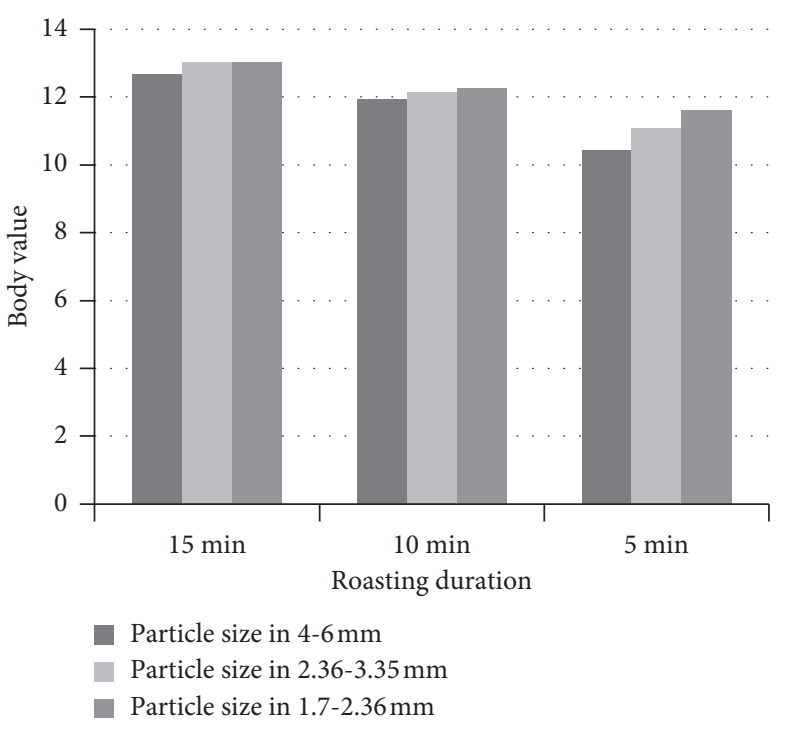

(b)

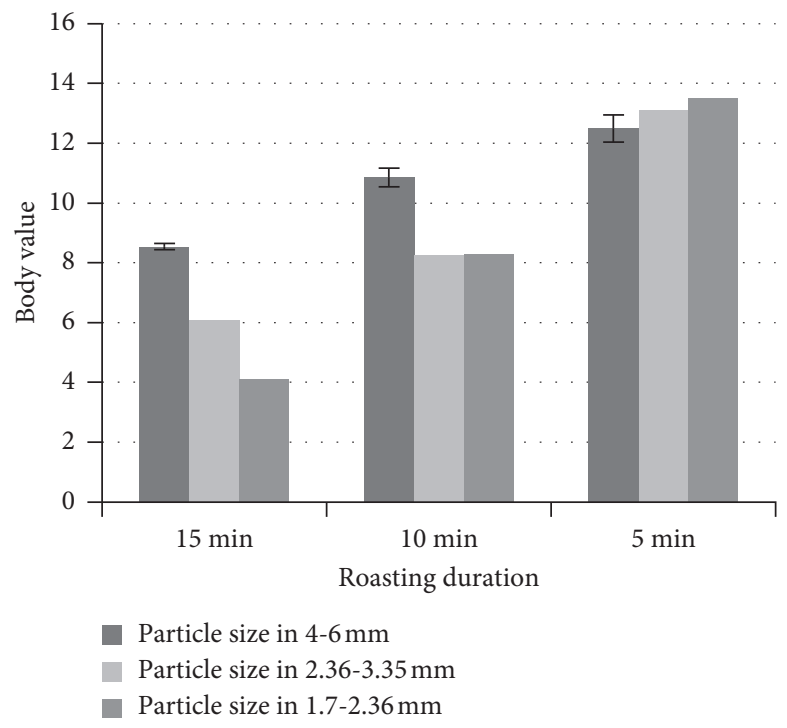

(c)

FiguRE 6: Effect of coffee bean particle size, roasting temperature, and roasting time on the body value of the coffee beverage. (a) Roasting temperature at $200^{\circ} \mathrm{C}$. (b) Roasting temperature at $230^{\circ} \mathrm{C}$. (c) Roasting temperature at $260^{\circ} \mathrm{C}$.

depending on the roasting time, temperature, and particle size.

The maximum caffeine content $(55.6 \mathrm{mg} / 250 \mathrm{ml})$ was observed in the coffee beverage prepared from the coffee bean roasted at $230^{\circ} \mathrm{C}$ for $10 \mathrm{~min}$ with $2.36-3.35 \mathrm{~mm}$ particle size (Table 2). As the caffeine content in the brew increased, the flavor acceptability decreased the sensory acceptability and is in agreement with Streit et al. [39]. To support the findings of the present study, different authors reported caffeine contents in coffee beverage in the similar ranges of the present study. For instance, Bertrand et al. [31] reported caffeine content in coffee brew as $49.5 \mathrm{mg} / \mathrm{L}$. Moreover, the caffeine content in Ethiopian Arabica (cultivar) coffee of Bench Maji, Gediyo Yirgachefe, Tepi, and Godare origins was reported as $56.3 \mathrm{mg} / \mathrm{L}, 55.8 \mathrm{mg} / \mathrm{L}, 56.2 \mathrm{mg} / \mathrm{L}$, and $56.15 \mathrm{mg} / \mathrm{L}$, respectively [40]. Therefore, the reported values are in reasonable degree of agreement with the findings of the present work. 




Particle size in 4-6 mm

Particle size in $2.36-3.35 \mathrm{~mm}$

- Particle size in $1.7-2.36 \mathrm{~mm}$

(a)

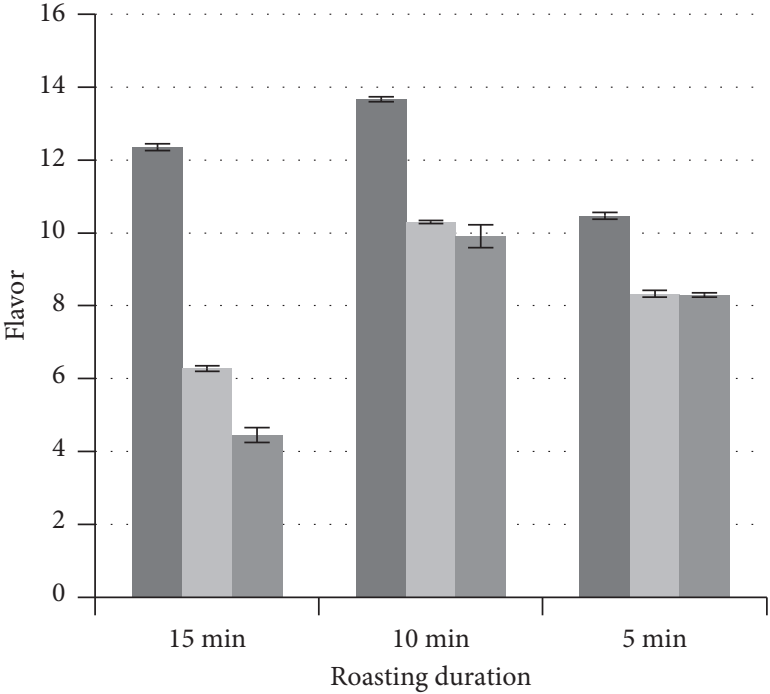

Particle size in 4-6 mm

Particle size in $2.36-3.35 \mathrm{~mm}$

- Particle size in $1.7-2.36 \mathrm{~mm}$

(b)

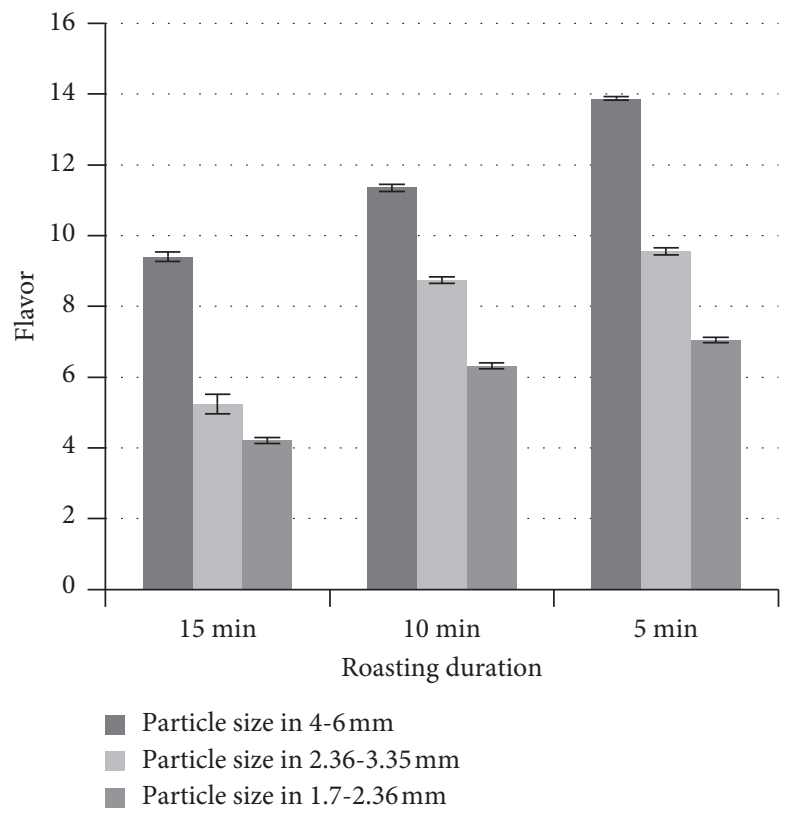

(c)

FiguRE 7: Effect of coffee bean particle size, roasting temperature, and roasting time on the flavor value of the coffee beverage. (a) Roasting temperature at $200^{\circ} \mathrm{C}$. (b) Roasting temperature at $230^{\circ} \mathrm{C}$. (c) Roasting temperature at $260^{\circ} \mathrm{C}$.

TABLE 2: Effect of coffee roasting temperature at $230^{\circ} \mathrm{C}$ for $10 \mathrm{~min}$ and $5 \mathrm{~min}$ time and particle size of $2.36-3.35 \mathrm{~mm}$ and $4-6 \mathrm{~mm}$ on caffeine content.

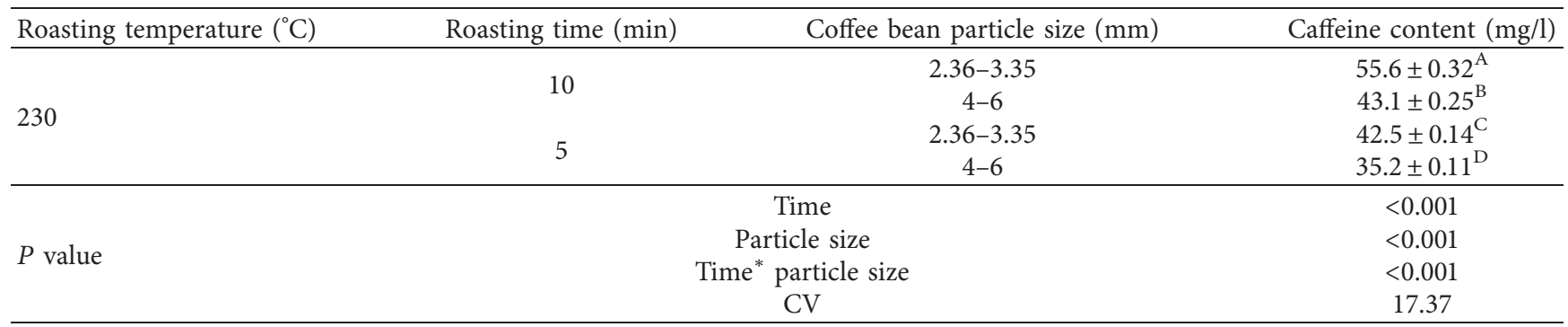

Means that do not share a letter in column are significantly different at $P<0.05$. Values are mean \pm standard deviation of three observations. 


\section{Conclusion}

The export standard LIMU cultivar coffee beans with a moisture content of $8.45 \%$ were used in this study. The raw values of the primary and secondary defects for odor, makeup and shape, and color showed a score of 37.6 out of 40; this concluded that the raw coffee beans used in this study did not show major defects. As the roasting temperature and duration increased, the dry mass was reduced in all the studied particle sizes. The roasted coffee bean has low bulk density than the raw beans due to the loss of mass and expansion of the volume during roasting. The change in bulk density decreases with the particle size reduction. The cup value and cup cleanness scores of the coffee brew prepared from all the particle sizes roasted at $200^{\circ} \mathrm{C}$ increased with roasting time and appreciated better foam stability and well settlement. Among the studied particle sizes, the acidity value increased with the roasting time at $200^{\circ} \mathrm{C}$ of roasting temperature. At $200^{\circ} \mathrm{C}$ and $230^{\circ} \mathrm{C}$, the migration of lipids and trigonelline to the bean surface facilitated and increased the body value of the brewed coffee as a function of roasting time. In case of flavor, size reduction facilitates volatilization of essential aroma component and minimizes the flavor value. Regarding the coffee total values, a particles size of $4-6 \mathrm{~mm}$ roasted at $230^{\circ} \mathrm{C}$ for $10 \mathrm{~min}$ provided the maximum total value of 89.21 out of 100 . The maximum caffeine content of $55.6 \mathrm{mg} / 250 \mathrm{ml}$ was registered in the brew prepared from the $2.36-3.35 \mathrm{~mm}$ particle sized coffee bean roasted at $230^{\circ} \mathrm{C}$ for $10 \mathrm{~min}$. However, further research is needed in order to corroborate these results.

\section{Data Availability}

The data used to support the findings of this study are available from the corresponding author upon request.

\section{Conflicts of Interest}

The authors declare that they have no conflicts of interest.

\section{Acknowledgments}

All the authors are grateful to the authorities of Bahir Dar Institute of Technology, Bahir Dar University, for providing the partial financial support (as the part of Masters study) and providing the laboratory facilities to finish this research. Also, they are grateful to the Ethiopian Coffee and Tea Authority, Coffee Quality Inspection and Certification Center (ECTACQICC), Addis Ababa, Ethiopia, officials for providing the raw coffee beans and expert panelists for sensory analysis.

\section{References}

[1] N. Pellegrini, M. Serafini, B. Colombi et al., "Total antioxidant capacity of plant foods, beverages and oils consumed in Italy assessed by three different in vitro assays," The Journal of Nutrition, vol. 133, no. 9, pp. 2812-2819, 2003.

[2] S. Heloisa Helena de and A. Celeste Maria Patto de, "Physicalchemical composition and quality of coffee submitted to two roasting procedures and to different methods of preparation," Ciencia e Agrotecnologia, vol. 30, no. 1, pp. 112-117, 2006.

[3] R. Clarke and O. Vitzthum, Coffee: Recent Developments, John Wiley \& Sons, New York, NY, USA, 2008.

[4] R. Eggers and A. Pietsch, "Roasting," in Coffee: Recent Developments, pp. 90-107, John Wiley \& Sons, New York, NY, USA, 2008.

[5] P. R. A. B. Toledo, L. Pezza, H. R. Pezza, and A. T. Toci, "Relationship between the different aspects related to coffee quality and their volatile compounds," Comprehensive Reviews in Food Science and Food Safety, vol. 15, no. 4, pp. 705-719, 2016.

[6] K. Speer and Kölling-Speer, "Lipids," in Coffee: Recent Developments, pp. 90-107, John Wiley \& Sons, New York, NY, USA, 2008.

[7] T. Kocadağlı, N. Göncüoğlu, A. Hamzalığlu, and V. Gökmen, "In depth study of acrylamide formation in coffee during roasting: role of sucrose decomposition and lipid oxidation," Food \& Function, vol. 3, no. 9, pp. 970-975, 2012.

[8] R. J. Redgwell, V. Trovato, D. Curti, and M. Fischer, "Effect of roasting on degradation and structural features of polysaccharides in Arabica coffee beans," Carbohydrate Research, vol. 337, no. 5, pp. 421-431, 2002.

[9] S. J. Lee, M. K. Kim, and K.-G. Lee, "Effect of reversed coffee grinding and roasting process on physicochemical properties including volatile compound profiles," Innovative Food Science \& Emerging Technologies, vol. 44, no. 1, pp. 97-102, 2017.

[10] A. S. Mujumdar, Handbook of Industrial Drying, CRC Press, Taylor \& Francis Group, New York, NY, USA, 2006.

[11] V. D. Nagaraju, K. Ramalakshmi, and B. S. Sridhar, "Cryo assisted spouted bed roasting of coffee beans," Innovative Food Science \& Emerging Technologies, vol. 37, no. 1, pp. 138-144, 2016.

[12] B. Bonnlander, R. Eggers, U. Engelhardt, and H. Maier, "Roasting," in Espresso Coffee: The Science of Quality, pp. 179-214, Acadamic press, San Diego, CA, USA, 2004.

[13] K. Burmester and R. Eggers, "Heat and mass transfer during the coffee drying process," Journal of Food Engineering, vol. 99, no. 4, pp. 430-436, 2010.

[14] ECX, Ethiopia Commodity Exchange Quality Operations Manual, ECX, Addis Ababa, Ethiopia, 2011.

[15] SCAA. "Specialty Coffee Association of America Standards" https://sca.coffee/research/coffee-standards.

[16] S. Abrar, M. Ali, and E. Solomon, "Processing method, variety and roasting duration effect on physical quality attributes of roasted Arabica coffee beans," Sky Journal of Agricultural Research, vol. 3, no. 5, pp. 53-61, 2014.

[17] S. Suwonsichon, E. Chambers, D. H. Chambers, and G. A. Milliken, "Effects of oral rinsing on the perception of residual cooling and burn in highly mentholated toothpaste," Journal of Sensory Studies, vol. 24, no. 2, pp. 290-300, 2009.

[18] E. Thomas, S. Puget, D. Valentin, and P. Songer, "Sensory evaluation-profiling and preferences," in The Craft and Science of Coffee, pp. 419-456, Acadamic press, San Diego, CA, USA, 2017.

[19] A. Khalid, S. Ahmad, H. Raza et al., "Determination of caffeine in soft and energy drinks available in market by using UV/ Visible Spectrophotometer," Family Medicine \& Medical Science Research, vol. 5, no. 4, 2016.

[20] P. Pittia, M. Dalla Rosa, and C. R. Lerici, "Textural changes of coffee beans as affected by roasting conditions," LWT-Food Science and Technology, vol. 34, no. 3, pp. 168-175, 2001.

[21] D. Perrone, R. Donangelo, C. M. Donangelo, and A. Farah, "Modeling weight loss and chlorogenic acids content in coffee 
during roasting," Journal of Agricultural and Food Chemistry, vol. 58, no. 23, pp. 12238-12243, 2010.

[22] S. Schenker, S. Handschin, B. Frey, R. Perren, and F. Escher, "Pore structure of coffee beans affected by roasting conditions," Journal of Food Science, vol. 65, no. 3, pp. 452-457, 2000.

[23] H. Schwartzberg, "Batch coffee roasting; roasting energy use; reducing that use," in Advances in Food Process Engineering Research and Applications, pp. 173-195, Springer, New York, NY, USA, 2013.

[24] J. A. Hernández, B. Heyd, C. Irles, B. Valdovinos, and G. Trystram, "Analysis of the heat and mass transfer during coffee batch roasting," Journal of Food Engineering, vol. 78, no. 4, pp. 1141-1148, 2007.

[25] R. Gmoser, R. Bordes, G. Nilsson et al., "Effect of dispersed particles on instant coffee foam stability and rheological properties," European Food Research and Technology, vol. 243, no. 1, pp. 115-121, 2017.

[26] Y. Arii and K. Nishizawa, "Espresso coffee foam delays cooling of the liquid phase," Bio Science, Biotechnology \& Biochemistry, vol. 81, no. 4, pp. 779-782, 2017.

[27] F. M. Nunes, M. A. Coimbra, A. C. Duarte, and I. Delgadillo, "Foamability, foam stability, and chemical composition of espresso coffee as affected by the degree of roast," Journal of Agricultural and Food Chemistry, vol. 45, no. 8, pp. 32383243, 1997.

[28] M. Fischer, S. Reimann, V. Trovato, and R. J. Redgwell, "Polysaccharides of green Arabica and Robusta coffee beans," Carbohydrate Research, vol. 330, no. 1, pp. 93-101, 2001.

[29] A. Oosterveld, A. G. J. Voragen, and H. A. Schols, "Effect of roasting on the carbohydrate composition of Coffea arabica beans," Carbohydrate Polymers, vol. 54, no. 2, pp. 183-192, 2003.

[30] S. H. Gaffney, A. Abelmann, J. S. Pierce et al., "Naturally occurring diacetyl and 2,3-pentanedione concentrations associated with roasting and grinding unflavored coffee beans in a commercial setting," Toxicology Reports, vol. 2, pp. 11711181, 2015.

[31] B. Bertrand, P. Vaast, E. Alpizar, H. Etienne, F. Davrieux, and P. Charmetant, "Comparison of bean biochemical composition and beverage quality of Arabica hybrids involving Sudanese-Ethiopian origins with traditional varieties at various elevations in Central America," Tree Physiology, vol. 26, no. 9, pp. 1239-1248, 2006.

[32] L. R. Perez-Alegria, V. H. J. Ciro, and L. C. Abud, "Physical and thermal properties of parchment coffee bean," Transactions of the ASAE, vol. 44, no. 6, pp. 1721-1726, 2001.

[33] G. A. Vargas-elías, P. C. Corrêa, N. R. D. Souza, F. M. Baptestini, and E. D. C. Melo, "Kinetics of mass loss of arabica coffee during roasting process," Engenharia Agrícola, vol. 36, no. 2, pp. 300-308, 2016.

[34] R. H. Stadler, N. Varga, J. Hau, F. A. Vera, and D. H. Welti, "Alkylpyridiniums. 1. Formation in model systems via thermal degradation of trigonelline," Journal of Agricultural and Food Chemistry, vol. 50, no. 5, pp. 1192-1199, 2002.

[35] R. A. Buffo and C. Cardelli-Freire, "Coffeeflavour: an overview flavour: an overview," Flavour and Fragrance Journal, vol. 19, no. 2, pp. 99-104, 2004.

[36] I. Blank, E. C. Pascual, S. Devaud et al., "Degradation of the coffee flavor compound furfuryl mercaptan in model Fentontype reaction systems," Journal of Agricultural and Food Chemistry, vol. 50, no. 8, pp. 2356-2364, 2002.

[37] T. Hofmann, M. Czerny, S. Calligaris, and P. Schieberle, "Model studies on the influence of coffee melanoidins on flavor volatiles of coffee beverages," Journal of Agricultural and Food Chemistry, vol. 49, no. 5, pp. 2382-2386, 2001.

[38] M. J. Lee, S. E. Kim, J. H. Kim, S. W. Lee, and D. M. Yeum, “A study of coffee bean characteristics and coffee flavors in relation to roasting," Journal of the Korean Society of Food Science and Nutrition, vol. 42, no. 2, pp. 255-261, 2013.

[39] N. Streit, L. Hecktheuer, M. Docanto et al., "Relation among taste-related compounds (phenolics and caffeine) and sensory profile of erva-mate (Ilex paraguariensis)," Food Chemistry, vol. 102, no. 3, pp. 560-564, 2007.

[40] A. Belay, K. Ture, M. Redi, and A. Asfaw, "Measurement of caffeine in coffee beans with UV/vis spectrometer," Food Chemistry, vol. 108, no. 1, pp. 310-315, 2008. 